\title{
PENGARUH PENAMBAHAN EKSTRAK DAUN JATI (Tectona grandis Linn. $f$ )DALAM PAKAN TERHADAP PERFORMA AYAM PETELUR
}

\author{
The Effect of Extract Tecton Leaf (Tectona grandis Linn. $f$ ) in Diet on \\ Performance of laying hen
}

\author{
Didik Nur Edi ${ }^{1}$, M. Halim Natsir' ${ }^{2)}$, dan Irfan Djunaidi ${ }^{2)}$ \\ 1) Mahasiswa Pascasarjana Fakultas Peternakan Universitas Brawijaya, Malang 65145, Indonesia \\ ${ }^{2)}$ Dosen Minat Nutrisi dan Makanan Ternak, Fakultas Peternakan Universitas Brawijaya, Malang 65145, \\ Indonesia \\ Email :didik17101987@gmail.com
}

\begin{abstract}
ABSTRAK
Tujuan dari penelitian iniadalah untuk mengetahui pengaruhpenambahan fitobiotik ekstrak daun jati (Tectona grandis Linn. f)sebagai alternatif pengganti antibiotic growth promotor dalam pakan terhadap performa ayam petelur. Materi yang digunakan adalah ayam petelurumur 30 minggu strain Isa Brown produksi PT. Charoen Pokphandsebanyak

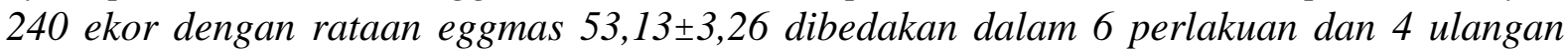
setiap ulangan terdapat 10 ekor ayam. Metode yang digunakan adalah penelitian eksperimental. Perlakuan yang dicobakan terdiri atas pakan basal tanpa ekstrak daun jati sebagai kontrol negatif (RO), pakan basal ditambah antibiotik virginamycin 0,015\% sebagai kontrol positif (R1), pakan basal ditambah ekstrak daun jati 0,4 (R2), 0,8 (R3), 1,2 (R4) dan 1,6\% (R5).Variabel yang diamati adalah konsumsi pakan harian(g/ekor/hari), hen day production(HDP) (\%), berat telur (g/butir), egg mass (g/ekor/hari), dan feed conversion ratio (FCR). Data dianalisis menggunakan analisis variansi (ANOVA) dari Rancangan Acak Lengkap (RAL) dan apabila terdapat perbedaan di lanjutkan dengan Uji Jarak Berganda Duncan's. Hasil penelitian menunjukkan bahwa penambahan ekstrak daun jati memberikan pengaruh yang sangat nyata $(P<0,01)$ terhadap konsumsi pakan harian, HDP, egg mass dan $F C R$ dan memberikan pengaruh yang nyata $(P<0,05)$ terhadap berat telur.Kesimpulan dalam penelitian ini adalah menambahkan ekstrak daun jati pada level 0,8\% dalam pakan untuk memperoleh performa ayam petelur terbaik.
\end{abstract}

Kata kunci: Antibiotik virginiamycin; ekstrak daun jati;performa ayam petelur

How to Cite :

Edi, N. D., Natsir, M. H., \& Djunaidi, I. (2018). Pengaruh Penambahan Ekstrak Daun Jati (Tectona grandis Linn. f) Dalam Pakan Terhadap Performa Ayam Petelur . Jurnal Nutrisi Ternak Tropis, 1 (1) 34 44
*Corresponding author:

Didik Nur Edi

Email : didik17101987@gmail.com

Faculty of Animal Science, Brawijaya University,

Veteran Street, Malang, East Java, Indonesia. 65145 


\section{ABSTRACT}

The purpose of this study was to determine theeffect of extract tecton leaf (Tectona grandis Linn. f) as feed additive on laying hen performa. The materials used were 240 laying hens of Isa Brown breed in 30 weeks of agewith egg mass average 53.13 3.26 and divided into six treatments and four replications.The method used was experiment. Treatments were devided into six groups i.e. without extract tecton leaf as negative control (RO), addition $0.015 \%$ of antibiotic virginiamycin in diet as positive control $(R 1)$ andwith extract tecton leaf $0.4 \%(R 2), 0.8 \%(R 3), 1.2 \%(R 4)$ and $1.6 \%(R 5)$.Variables measured in this experiment were consumtion, HDP, egg weight, egg mass, FCR. The data ware analyzed by Completely Randomized design. If significant effect detected, then were calculated by the Duncan Multiple Range Test.The result showed that the adding extract tecton leaf in the laying hen diet highly significanteffect $(P<0.01)$ on consumtion, HDP, egg mass, FCR and gave significant effect $(P<0.05)$ on egg weight. Conclusion is addition of $0.8 \%$ extract tecton leaf in the feed gives the best effect on the performance of production.

Keywords: Antibiotic virginiamycin; extracttecton grandis linn f; laying hen performa

\section{PENDAHULUAN}

Pakan yang berkualitas diperlukan untuk menunjang performa ternak yang optimal. Upaya peningkatan kualitas pakan salah satunya adalah dengan ditambahnya additive dalam pakan (Haryuni dkk., 2017). Pada umumnya penambahan additive pakan dapat berupa antibiotik, prebiotik, probiotik, enzim, asam organik, fitobiotik atau bioaktif tanaman dan minyak esensial (Magdalenaet al., 2014).

Feed additive berupa antibiotik secara luas telah digunakan oleh peternak ayam petelur untuk meningkatkan efisiensi penggunaan pakan, meningkatkan produksi dan menjaga kesehatan ternak (Cervantes, 2012). Penambahan antibiotik untuk imbuhan pakan sejak Mei 2017 telah dilarang yang tertuang dalampasal 16 ayat 2 Permantan RI nomor 14/PERMENTAN/PK.350/5/2017 tentang Klasifikasi Obat Hewan. Residu antibiotik pada produk ternak dapat mengakibatkan resisten pada tubuh ternak, resiko kurang baik bagi kesehatan manusia apabila mengkonsumsi produk tesebut, resisten pada bakteri patogen seperti Campylobacter, Salmonella, Enterococcus dan Escherichia coli (Grahamet al., 2007).

Menurut Iwantoro (2018) dampak negatif bagi kesehatan manusia akibat residu antibiotik dari produk ternak yaitureaksi alergi, toksisitas, mempengaruhi flora usus, respon immun dan resistensi terhadap mikroorganisme. Menurut Sinurat dkk., (2003) salah satu alternatif yang dapat dilakukan yaitu dengan mengganti antibiotik menggunakan fitobiotik.

Fitobiotik adalah tanaman herbal yang memiliki bahan aktif yang dapat bersifat antibakteri dapat memperbaiki kondisi saluran pencernaan (keseimbangan $\mathrm{pH}$ dan mikroflora), konversi pakan, meningkatkan kecernaan zat-zat makanan dan meningkatkan performa (Ramiah et al., 2014). Daun jati (Tectona grandis Linn. f) merupakan salah satu fitobiotik yang belum banyak digunakan untuk feed additive ayam petelur dan keberadaannya sangat luas.Ekstrak daun jati mengandung beberapa bioaktif diantaranya adalah flavonoid, steroid dan antosianin serta memiliki aktifitas antibakteri, antijamur, antioksidan (Khera and Bhargava, 2013).Sahay and Sharma (2015) dan Ernawati dkk., (2014) menambahkan daun jati muda memilikikandungan pigmen alami yang terdiridari antosianin, pheophiptin, $\beta$-karoten, pelargonidin 3glukosida, pelargonidin 3,7-diglukosida, klorofil dan dua pigmen lain yang belum diidentifikasi. Terkait adanya kandungan 
bioaktif, aktifitas antibakteri dan didukung dengan teknologi ekstraksi dimungkinkan akan memaksimalkan kandungan bioaktif daun jati biladigunakan sebagai feed additive sehingga dilakukan penelitian lebih lanjut mengenai pengaruh penambahan ekstrak daun jati pada pakan terhadap performa ayam petelur sebagai salah satu alternatif pengganti antibiotic growth promotor.

\section{MATERI DAN METODE}

Penelitian menggunakan 240 ekor ayam petelur strain isa brownumur 30 minggu yang dikelompokkan dalam 6 perlakuan dan 4 ulangan. Setiap ulangan terdapat 10 ekor ayamdengan rataan egg mass $53,13 \pm 3,26$.Pakan yang digunakan pada penelitian disusun seperti pada Tabel 1 dengan kandungan nutrisi disesuaikan dengan rekomendasi dari Buku Panduan Manajemen Ayam Petelur Komersial HyLine Brown 2014. Pemberian pakan 125 g/ekor/hari. Pemberian air minum secara ad libitum. Additive pakan yang digunakan berupa antibiotik virginiamycin dan ekstrak daun jati.

Tabel 1. Komposisi dan kandungan nutrisi pakan basal penelitian.

\begin{tabular}{lcc}
\multicolumn{1}{c}{ Bahan Pakan } & Komposisi* $(\%)$ & Harga $(\mathrm{Rp} / \mathrm{kg})$ \\
\hline Jagung & 54,32 & 4.050 \\
Bekatul & 8,69 & 2.700 \\
Bungkil kedelai & 18,16 & 7.800 \\
Meat bone meal & 8,00 & 7.500 \\
Minyak kelapa sawit & 1,50 & 7.200 \\
Tepung batu & 2,88 & 500 \\
Menir batu & 5,76 & 500 \\
Natrium bikarbonat & 0,09 & 7.500 \\
Antijamur & 0,08 & 65.000 \\
Garam & 0,11 & 3.500 \\
Choline Cloride 60\% & 0,04 & 21.000 \\
Lisin HCl & 0,14 & 23.000 \\
DL Metionin $99 \%$ & 0,17 & 47.000 \\
Trace mineral & 0,03 & 37.500 \\
Vitamin & 0,02 & 120.000 \\
Jumlah & 100 & 4821,34 \\
\hline Kandungan & Perhitungan* & Analisis** \\
\hline EM (Kkal/Kg) & 2829,93 & 2496,90 \\
Bahan kering $(\%)$ & 88,38 & 88,78 \\
Abu (\%) & 11,99 & 11,04 \\
Protein kasar $(\%)$ & 17,88 & 17,74 \\
Lemak kasar $(\%)$ & 5,64 & 5,43 \\
Serat kasar $(\%)$ & 2,92 & 7,26 \\
Kalsium $(\%)$ & 4,08 & 4,34 \\
Fospor total $(\%)$ & 0,78 & 0,78 \\
\hline Keterangan: & &
\end{tabular}

Keterangan:

* Hasil perhitungan menggunakan program WinFeed 2.8 dengan basis data nutrient dari Buku Panduan Manajemen Ayam Petelur Komersial Hy-Line Brown, 2014

**Hasil analisa Lab. Pakan Ternak Dinas Peternakan dan Perikanan Kabupaten Blitar, EM merupakan hasil perhitungan Analisis Lab. berdasarkan 70 \% GE. 
Metode penelitian yang digunakan adalah percobaan lapang menggunakan Rancangan Acak Lengkap (RAL) dan dilanjut uji Jarak Berganda Duncan's apabila terdapat perbedaan penggaruh. Terdiri atas 6 perlakuan dan 4 ulangan. Setiap ulangan terdiri dari 10 ekor. Level pemberian ekstrak daun jati pada pakan basal adalah sebagai berikut :

$\mathrm{R} 0=$ Pakan basal (tanpa antibiotik)

$\mathrm{R} 1=$ Pakan basal + Virginiamycin $0,015 \%$

$\mathrm{R} 2=$ Pakan basal + Ekstrak daun jati 0,4\%

R3 = Pakan basal + Ekstrak daun jati 0,8\%

R4 = Pakan basal + Ekstrak daun jati 1,2\%

R5 = Pakan basal + Ekstrak daun jati 1,6\%

Pembuatan ekstrak diawali dengan pembuatan simplisia berupa tepung yang dibuat dengan melayukan daun jati selama 24 jam kemudia dikeringkan dengan oven pada suhu $45^{\circ} \mathrm{C}$ selama 36 jam kemudian digiling hingga menjadi tepung. Maserasi dilakukan dengan merendam simplisia daun jati selama 36 jam dengan larutan etanol $70 \%$, kemudian filtrat diuapkan dengan evaporator dengan kecepatan putar $90 \mathrm{RPM}$, suhu bath tube $60^{\circ} \mathrm{C}$ dan suhu dalam tabung $40^{\circ} \mathrm{C}$, hingga diperoleh cairan ekstrak kental. Ekstrak kental daun jati kemudian ditambahkan dalam pakan basal sesuai dengan level percobaan dengan cara di spray kemudian diaduk hingga homogen. Pencampuran ini dilakukan setiap pagi sebelum pakan diberikan ke ayam petelur.

Variabel penelitian yang diamati adalah konsumsi pakan harian (g/ekor/hari), Hen day production (\%), berat telur (g/butir), egg mass (g/butir/hari) dan feed conversion ratio(FCR).

\section{HASIL DAN PEMBAHASAN}

Pemeriksaan pendahuluan untuk mengetahuikarakteristik dari ekstrak daun jati dalam penelitian ini dilakukan dengan menganalisis kandungan biokimia ekstrak daun jati meliputi flavonoid, antioksidan dan antosianin dapat dilihat pada Tabel 2.

Tabel 2. Kandungan biokimia ekstrak daun jati.

\begin{tabular}{ll}
\hline \multicolumn{1}{c}{ Analisis } & Hasil analisis \\
\hline Flavonoid & $128,69 \mathrm{mg} / 100 \mathrm{~g}$ \\
Antosianin & $83,89 \mathrm{ppm}$ \\
Antioksidan & $47,61 \%$ \\
\hline
\end{tabular}

Keterangan : Hasil analisis laboratorium pusat studi pangan dan gizi, UGM

Kandungan flavonoid ekstrak daun jati sebesar 128,69 mg/100g (Tabel 2),lebih tinggi dari yang dilaporkan oleh Kushwah (2013) yaitu sebesar $2,99 \mathrm{mg} / 100 \mathrm{~g}$ (pelarut metanol); Rahardhinata dan Sani (2012) yaitu $22,58 \mathrm{mg} / 100 \mathrm{~g}$ (pelarut etanol, asam asetat dan air dengan perbandingan $21: 1$ : 3) dan lebih rendah dari hasil penelitian Ahmadi (2015) yaitu sebesar $241 \mathrm{mg} / 100 \mathrm{~g}$ (pelarut air); Ghareeb et al., (2014) yaitu $3055 \mathrm{mg} / 100 \mathrm{~g}$ (pelarut etanol 70\%).

Hasil uji kuantitatif antosianin ekstrak daun jati sebesar 83,89 ppm lebih tinggi dari laporan penelitian sebelumnya yaitu 4,258 ppm (Ernawati et al., 2014) dan lebih redah dari laporan Fathinatullabibah dkk., (2014) yaitu sebesar 284,72 ppm.
Kandungan antioksidan ekstrak daun jati sebesar 47,61\% mendekati dengan laporan Rahardhinata dan Sani (2012) yaitu $36,55 \%$; Sahay and Sharma (2015) yaitu $46,7 \%$ dan lebih tinggi dari yang dilaporkan Ghareeb et al., (2014) yaitu $1,958 \%$. Perbedaan kandungan bioaktif flavonoid, antosianin dan antioksidan dari beberapa laporan penelitian disebabkan karena perbedaan metode ekstrasi dan pelarut.

Data hasil penelitian eksperimental menunjukkan bahwa penambahan ekstrak daun jati pada pakan ayam petelur berpengaruh sangat nyata $(\mathrm{P}<0,01)$ terhadap konsumsi pakan harian, HDP, berat telur, dan egg mass dan memberikan 
perbedaan yang nyata $(\mathrm{P}<0,05)$ terhadap FCR. Pengaruh penambahan ekstrak daun jati terhadap performa ayam petelur dapat dilihat pada Tabel 3.

Tabel 3. Pengaruh penambahan ekstrak daun jati terhadap performa ayam petelur

\begin{tabular}{cccccc}
\hline Perlakuan & $\begin{array}{c}\text { Konsumsi* } \\
\text { (g/ekor/hari) }\end{array}$ & $\begin{array}{c}\text { HDP* }^{*} \\
(\%)\end{array}$ & $\begin{array}{c}\text { Berat telur** } \\
\text { (g/butir) }\end{array}$ & $\begin{array}{c}\text { Eggmass* } \\
(\mathrm{g} / \text { /butir/hari })\end{array}$ & FCR $^{*}$ \\
\hline R0 & $106,51^{\mathrm{ab}} \pm 1,28$ & $73,33^{\mathrm{a}} \pm 0,93$ & $58,30^{\mathrm{a}} \pm 1,25$ & $42,72^{\mathrm{a}} \pm 1,36$ & $2,51^{\mathrm{b}} \pm 0,087$ \\
R1 & $108,50^{\mathrm{ab}} \pm 0,79$ & $88,45^{\mathrm{b}} \pm 0,54$ & $61,65^{\mathrm{b}} \pm 1,50$ & $54,54^{\mathrm{b}} \pm 1,63$ & $1,97^{\mathrm{a}} \pm 0,036$ \\
R2 & $105,28^{\mathrm{a}} \pm 1,98$ & $74,25^{\mathrm{a}} \pm 0,42$ & $58,77^{\mathrm{a}} \pm 0,95$ & $43,61^{\mathrm{a}} \pm 0,51$ & $2,43^{\mathrm{b}} \pm 0,078$ \\
R3 & $109,89^{\mathrm{b}} \pm 2,42$ & $88,33^{\mathrm{b}} \pm 0,49$ & $60,22^{\mathrm{ab}} \pm 1,68$ & $53,19^{\mathrm{b}} \pm 1,28$ & $2,07^{\mathrm{a}} \pm 0,050$ \\
R4 & $108,94^{\mathrm{ab}} \pm 1,73$ & $87,78^{\mathrm{b}} \pm 0,45$ & $60,09^{\mathrm{ab}} \pm 0,85$ & $52,74^{\mathrm{b}} \pm 0,65$ & $2,07^{\mathrm{a}} \pm 0,046$ \\
R5 & $109,92^{\mathrm{b}} \pm 1,56$ & $88,21^{\mathrm{b}} \pm 0,27$ & $61,18^{\mathrm{b}} \pm 1,19$ & $53,97^{\mathrm{b}} \pm 1,00$ & $2,04^{\mathrm{a}} \pm 0,012$ \\
\hline
\end{tabular}

Keterangan: ${ }^{a b}$ Nilai rata-rata pada baris yang sama dengan superskrip yang berbeda menunjukkan perbedaan yang sangat nyata $(P<0,01)^{* \text { ab }}$ Nilai rata-rata pada baris yang sama dengan superskrip yang berbeda menunjukkan perbedaan yang nyata $(P<0,05)^{* *}$

\section{Konsumsi pakan harian}

Analisis statistik pada Tabel 3 menunjukkan bahwa penambahan ekstrak daun jati dalam pakan berpengaruh sangat nyata $(\mathrm{P}<0,01)$ terhadap konsumsi pakan harian. Perlakuan penambahan ekstrak daun jati meningkatkan konsumsi dibandingkan dengan kontrol. Hal ini menunjukkan dengan ditambahnya ekstrak daun jati dalam pakan dapat meningkatkan konsumsi.

Hasil uji Jarak Berganda Duncan's menunjukkan konsumsi terendah $(105,28 \pm 1,98$ g/ekor/hari) pada penambahan ekstrak daun jati dalam pakan denganlevel $0,4 \%$. Konsumsi pada R1 (penambahan ekstrak daun jati 0,4\%) lebih rendah $1,86 \%$ dari pakan basal karena dalam ekstrak daun jati terdapat tanin (Godghate and Sawant, 2014),yang dimungkinkan pengaruhnya lebih kuat dibandingkan flavonoid. Tanin merupakan senyawa anti-nutrisi dengan kemampuannya untuk membentuk kompleks dengan protein yang terdapat pada pakan sehingga protein tersebut tidak dapat dicerna terutama oleh ternak monogantrik (Magdalena dkk., 2014). Hasil ini sesuai dengan penelitian Anita dkk., (2012) menyebutkan pemberian tepung daun teh sebesar 4,5\% yang mengadung tanin dapat menurunkan konsumsi ayam broiler hingga $3,2 \%$.
Peningkatan konsumsi mulai terjadi pada level pemberian ekstrak daun jati sebesar $0,8 \%$ dan secara statistik level penambahan $0,8-1,6 \%$ menunjukkan hasil yang sama dengan pakan basal dan pakan yang ditambah antibiotik virginiamycin $0,015 \%$ tetapi secara numerik semakin tinggi level pemberian ekstrak daun jati menyebabkan konsumsi semakin naik. Konsumsi ayam dalam penelitian ini adalah 105,28-109,92 g/ekor/hari sesuai dengan standar dari buku Panduan Manajemen Ayam Petelur Komersial Hy-Line Brown Tahun 2014 yaitu 100-120 g/ekor/hari.

Peningkatan konsumsi terjadi karena beberapa faktor diantaranya semakin tinggi level penambahan ekstrak daun jati menjadikan kondisi pakan semakin basah akibat kandungan air ekstrak daunjati yang tinggi mencapai 93,43\% sehingga dapat meningkatkan palatabilitas ternak. Forbes (2003) menjelaskan kondisi pakan basah mempengaruhi konsumsi dan palatabilitas karena teksturpakan menjadi lebih lembut. Emadinia et al., (2014) menambahkan kondisi pakan basah dapat meningkatkan konsumsi karena kandungan air dalam pakan dapat meningkatkan passing ratedigesta dalam saluran pencernaan, meningkatkan palatabilitas, menaikkan nutrient utilization, dan mengurangi minum untuk meningkatkan konsumsi. 
Beberapa penelitian juga menunjukkan hasil yang sama diantaranya dilaporkan oleh dilaporkan oleh Afsharmanesh et al., (2016), pada penelitiannya pemberian pakan secara $a d$ libitumdengan kondisi pakan basah dapat meningkatkan konsumsi pakan ayam pedaging dari pada pakan kering yaitu dari 150,91 g/ekor/hari menjadi 166,56 g/ekor/hari. Sejalan dengan itu, Diarra and Tabuaciri (2014) melaporkan penambahan air pada pakan dengan rasio 1 : 1 (air : pakan) pada suhu lingkungan tinggi dapat meningkatkan konsumsi pada ayam petelur. Bintang dkk., (2014) menambahkan, pemberian ampas mengkudu menyebabkan kondisi pakan menjadi basah dapat meningkatkan konsumsi ayam petelur dari 103 g/ekor/hari menjadi 104 g/ekor/hari. Prahadi dkk., (2015) melaporkan penambahan sari belimbing wuluh (Averrhoa bilimbi L.) sebagai acidifier dalam pakan terhadap penampilan produksi ayam petelurdapat meningkatkan konsumsi dari 137,16 g/ekor/hari menjadi 138,63 g/ekor/hari karena kodisi pakan menjadi lebih basah.

Selain bentuk basah peningkatan konsumsi juga dapat dikarenakan dalam ekstrak daun jati mengandung bioaktif seperi flavonoid, antioksidan dan antosianin. Prabakar et al., (2016) menyatakan bioaktif dari fitobiotik dapat meningkatkan palatibilitas dan kualitas pakan (sensory aspects). Flavonoid merupakan metabolit sekunder dari tanaman yang memiki sifat antibakteri, antijamur, anti-inflamasi (Khera and Bhargava, 2013), sehingga dengan ditambahnya ekstrak daun jati dapat menyeimbangkan mikroflora usus, mengoptimalkan saluran pencernaan, meningkatkan proses pencernaan pakan. Ramiah et al., (2014) menjelaskan keseimbangan populasi mikroba dalam saluran pencernaan unggas sangatlah penting dalam proses pencernaan dan kesehatan serta dapat meningkatkan konsumsi broiler yaitu 45,15 menjadi 47,70 g/ekor/hari.

\section{Hen day production(HDP)}

Penambahan ekstrak daun jati dalam pakan secara statistik berpengaruh sangat nyata $(\mathrm{P}<0,01)$ terhadap HDP (Tabel 3$)$. Hal ini menunjukkan bahwa penambahan ekstrak daun jati pada pakan dapat meningkatkan HDP. Hasil uji Jarak Berganda Duncan's menunjukkan peningkatan HDP mulai terjadi pada penambahan ekstrak daun jati pada level 0,8\% dan secara statistik nilai HDP pada pemberian ekstrak daun jati antara 0,$8 ; 1,2$ dan $1,6 \%$ adalah sama. Hal ini menggambarkan penambahan ekstrak daun jati dengan level antara $0,8-1,6 \%$ dalam pakan memberikan respon terhadap HDP yang sama. Selain itu juga menggambarkan penambahan ekstrak daun jati dengan level 0,8-1,2\% menunjukkan hasil yang sama dengan penambahan antibiotik virginiamycin $0,015 \%$ pada pakan terhadap HDP.

Peningkatan HDP disebabkan karena ekstrak daun jati mengandung bioaktif flavonoid, antioksidan dan antosianin yang memiliki aktifitas antibakteri, sehingga dapat menurunkan bakteri patogen. Hartono dan Kurtini (2017) melaporkan mikroba dalam saluran pencernaan dapat merangsang sel globet pada dinding halus untuk memproduksi mukus, dengan peningkatan mukus dapat meningkatkan penyerapan nutriens, sehingga pada gilirannya dapat memaksimalkan HDP.

Prabakar et al., (2016) menjelaskan bahwa kandungan fitobiotik dalam tanaman yang bekerja secara sinergi antara bioaktif, kimia organik dan komponen organik dapat meningkatkan produksi karena memiliki sifat antibakteri.Iskender et al., (2017) menyatakan penambahan flavonoid 0,5 $\mathrm{g} / \mathrm{kg}$ dapat meningkatkan produksi, kesehatan dan performa ternak. Ramiah et al., (2014) menyatakan populasi mikroflora dalam saluran pencernaan unggas sangat penting yang mempengaruhi proses pencernaan pakan dan kesehatan ternak. Świątkiewiczet al., (2018) menambahkan 
peningkatan penyerapan pakan dapat memaksimalkan produksi telur.

Beberapa hasil penelitian menunjukkan hasil yang sama diantaranya Haryuni (2017), melaporkan penambahan jus daun sirih yang mempunyai sifat antibakteri dapat meningkatkan HDP ayam petelur dari 69,48 menjadi 76,43\%. Satriadkk., (2016) melaporkan penambahan jus daun kelor yang mengandung flavonoid dan mempunyai aktivitas antibakteri dapat meningkatkan HDP.

\section{Berat telur}

Analisis statistik pada Tabel 3menunjukkan bahwa penambahan ekstrak daun jatidalam pakan memberikan pengaruh nyata $(\mathrm{P}<0,05)$ terhadap berat telur. Perlakuan penambahan ekstrak daun jati mempunyai nilai berat telur lebih tinggi dari pada kontrol. Hal tersebut menunjukkan bahwa penambahan ekstrak daun jati dalam pakan dapat meningkatkan berat telur. Hasil uji jarak berganda duncun`s menunjukkan bahwa penambahan ektrak daun jati dengan level $0,4 \%$ belum mampu meningkatkan berat telur, peningkatan mulai terjadi dengan pemberian ekstrak daun jati dalam pakan pada level $0,8 \%$. Secara statistik penambahan ekstrak daun jati dengan level $0,8-1,6 \%$ sama dengan penambahan antibiotik virginiamicin $0,015 \%$ dalam pakan.

Peningkatan berat telur sejalan dengan peningkatan konsumsi dan peningkatan level pemberian ekstrak daun jati. Peningkatan konsumsi menjadikan zat makanan yang masuk meningkat (diantaranya protein) dan peningkatan konsumsi ini sejalan dengan kandunganbioaktif terutama flavonoid yang mempunyai sifat antibakteri sehingga pada gilirannya akan meningkatkan berat telur.

Menurut Brisbin et al., (2008) berkurangnya bakteri patogen pada saluran pencernaan ayam dapat meningkatkan kecernaan pakan, mengoptimalkan penyerapan zat makanan dan meningkatkan bakteri yang berguna bagi untuk induk.
Hasil penelitian Iskander et al (2017) melaporkan suplementasi flavonoid 0,5 $\mathrm{g} / \mathrm{kg}$ berupa quercetin dapat meningkatkan total protein telur dari 14,28 menjadi 14,85 g/100 g. Bintang et al., (2014) menambahkan bahwa kecernaan pakan terutama protein berkorelasi positif dengan peningkatan berat telur.

Hasil penelitian Haryuni (2017) menunjukkan kandungan protein pada pakan akan mempengaruhi komposisi telur dan bobot telur yang dihasilkan. Protein yang tinggi dalam pakan akan mempengaruhi sinteis albumen dan kuning telur (Horhoruw et al., 2009), sedangkan albumen dan kuning telur merupakan kompenen terbesar dalam di dalam telur yaitu secara berurutan 67,51 dan 23,15\% (Siloto et al., 2011) sehingga akan berpengaruh dengan berat telur.

\section{Egg mass}

Analisis statistik menunjukkan bahwa penambahan ekstrak daun jati dalam pakan memberikan pengaruh sangat nyata $(\mathrm{P}<0,01)$ terhadap eggmass (Tabel 3$)$. Hal tersebut menunjukkan penambahan ekstrak daun jati dapat meningkatkan eggmas. Uji jarak berganda duncun`s menunjukkan bahwa pemberian ekstrak daun jati dengan level $0,4 \%$ pada pakan belum dapat meningkatkan egg mass. Peningkatan egg mass mulai terlihat pada penambahan ekstrak daun jati pada level $0,8 \%$ dan hingga level $1,6 \%$ secara statistik membeikan hasil yang sama dengan pemberian antibitik virginiamicin $0,015 \%$.

Peningkatan eggmas pada penelitian ini terjadi karena peningkatan HDP dan berat telur, karena secara matematis egg massmerupakan hasil perkalian dari HDP dan berat telur sehingga nilainya akan berbanding lurus. Menurut Świątkiewiczet al (2018) beberapa faktor yang mempengaruhi egg mass adalah feed additive, konsumsi, kandungan kalsium pakan, ukuran telur dan berat telur. 
Feed conversion ratio (FCR)

Analisis statistik menunjukkan bahwa penambahan ekstrak daun jati dalam pakan memberikan pengaruh sangat nyata $(\mathrm{P}<0,01)$ terhadap FCR (Tabel 3). Hasil tersebut menunjukkan bahwa pemberian ektrak daun jati mampu meningkatkan efisiensi pakan. Uji jarak berganda duncun`s memperlihatkan bahwa penambahan ekstrak daun jati pada level $0,4 \%$ dalam pakan belum mampu meningkatkanFCR.Penggunaan esktrak daun jati pada minimal $0,8 \%$ dapat meningkatkanFCR dan secara statistik memberikan hasil yang sama dengan pemberian ektrak daun jati hingga level 1,6\%. Penambahan ektrak daun jati $0,8-$ $1,6 \%$ secara statistik mengahasilkan FCR sama dengan penambahan antibiotik virginamycin $0,015 \%$ dalam pakan.

Nilai FCR mengalami peningkatkan seiring dengan level penambahan ekstrak daun jati. Menurut Haryuni (2017), konversi pakan dapat digunakan untuk menduga keuntungan. Semakin rendah konversi pakan maka hasil yang diperoleh akan semakin menguntungkan. FCR rendah disebabkan karena kecernaan pakan meningkat dengan ditambahnya ekstrak daun jati sehingga menyebabkan angka konversi ransum lebih rendah.Kecernaan pakan meningkat karena dalam ekstrak daun jati terdapat bioktif flavonoid, antioksidan dan antosianin. Karena bioaktif tersebut mempunyai aktivitas antibakteri, antioksidan, antijamur yang dapat meningkatkan fungsi saluran pencernaan (Khera and Bhargava, 2013; Brisbin et al., 2008). Prabakar et al.,(2016) menjelaskan fitobiotik dapat bersifat antibakteri, antioksidan dan dapat menekan stress pada unggas, sehingga penambahan fitobiotik pada pakan unggas dapat meningkatkan FCR, fungsi saluran pencernaan, kecernaan pakan, sistem imun.

Hasil ini sejalan dengan penelitian Satria dkk., (2016) melaporkan bahwa pemberian tepung daun kelor $2 \%$ (memiliki kandungan flavonoid dan antioksidan) pada pakan dapat menurunkan FCR ayam petelur hingga 2,04 $\pm 0,01$ sedangkan pada penelitian ini FCR terendah sebesar 2,04 $\pm 0,012$ pada penambahan ektrak daun jati sebesar $1,6 \%$ pada pakan.

\section{KESIMPULAN}

Pemberian ekstrak daun jati minimal 0,8\% dalam pakan menghasilkan performa ayam petelur (konsumsi, HDP, berat telur, eggmass dan FCR sama dengan penambahan antibiotik virginamicin $0,015 \%)$. Saran yang dapat diberikan adalah menambahkan ekstrak daun jati dengan level $0,8 \%$ dalam pakan ayam petelur untuk alternatif pengganti antibiotik virginiamicin.

\section{UCAPAN TERIMA KASIH}

LPDP (Lembaga Pengelola Dana Pendidikan) Kementrian Keuangan yang telah membiayai selama kuliah dan penelitian di Universitas Brawijaya Malang.

\section{DAFTAR PUSTAKA}

Afsharmanesh, M., Lotfi, M., \& Mehdipour, Z. (2016). Effects of wet feeding \& early feed restriction on blood parameters \& growth performance of broiler chickens. Animal Nutrition, 2(3), 168-172. https://doi.org/10.1016/j.aninu.2016.0 4.002

Ahmadi, S. E. T., (2015). Penambahan tepung \& ekstrak daun jati (Tectona grandis Linn. f) pada puyuh Coturnix japonica. Tesis. Institut Pertanian Bogor. Sekolah Pascasarjana Program Studi Nutrisi \& Pakan.

Anita, W. Y., Astuti, I., \& Suharto. (2012). Pengaruh pemberian tepung daun teh tua dalam ransum terhadapperforman $\&$ persentase lemak abdominal ayam broiler. Tropical Animal Husbandry, 1(1), 1-6. 
Anonimus. (2014). Panduan manajemen : ayam petelur komersial hy-line brown. Hy-Line International EggCel. www.hyline.com

Bintang, I. A. K., Sinurat, A. P., \& Purwadaria, T. (2014). Penambahan antibiotika \& bioaktif ampas mengkudu terhadap produksi telur ayam. Jurnal Ilmu Ternak \& Veteriner, 19(3), 83-88.

Brisbin, J. T., Gong, J., Lusty, C. A., Sabour, P., Sanei, B., Han, Y., Sharif, S. (2008). Influence of in-feed virginiamycin on the systemic \& mucosal antibody response of chickens. Poultry Science, 87(10), 1995-1999.

https://doi.org/10.3382/ps.200800159

Cervantes, H. M. (2012). The future of antibiotic growth promoters in poultry production. In Worlds Poultry Congress, XXIV.

Diarra, S. S., \& Tabuaciri, P. (2014). Feeding management of poultry in high environmental temperatures. International Journal of Poultry Science, 13(11), 657-661.

Emadinia, A., Toghyani, M., Gheisari, A., Tabeidian, S. A., Ale Saheb Fosoul, S. S., \& Mohammadrezaei, M. (2014). Effect of wet feeding \& enzyme supplementation on performance $\&$ immune responses of broiler chicks. Journal of Applied Animal Research, 42(1), 32-37. https://doi.org/10.1080/09712119.201 3.795901 .
Ernawati, U. R., Khasanah, L. U., \& Anandito, R. B. K. (2014). The effect of variation dextrose equivalents maltodextrin values on the microencapsulant characteristic of teak leaves (tectona grandis lf) natural dye. Jurnal Teknologi Pertanian, 15(2), 111-120.

Fathinatullabibah, F., Khasanah, L. U., \& Kawiji, K. (2014). Stabilitas antosianin ekstrak daun jati (Tectona grandis) terhadap perlakuan $\mathrm{pH} \&$ suhu. Jurnal Aplikasi Teknologi Pangan, 3(2), 60-63.

Forbes, J. M. (2003). Wet foods for poultry. avian \& poultry biology reviews, 14(4), 175-193. https://doi.org/10.3184/14702060378 3637481 .

Ghareeb, M. A., Hussein, A. H., Hassan, M. F. M., Laila, A. R., Mona, A. M., \& Amal, M. S. (2014). Antioxidant \& cytotoxic activities of Tectona grandis linn leaves. International Journal of Phytopharmacology, 5(2), 143-157.

Godghate, A. G., \& Sawant, R. S. (2014). Phytochemical analysis of leaves of tectona grandis linn. Int J Pharm Bio Sci, 5(1), 355-359.

Graham, J. P., Boland, J. J., \& Silbergeld, E. (2007). Growth promoting antibiotics in food animal production: an economic analysis. Public Health Reports, 122(1), 79-87.

Hartono, M., \& Kurtini, T. (2017). Pengaruh pemberian probiotik terhadap performa ayam petelur. Jurnal Penelitian Pertanian Terapan, 15(3), 214-219. 
Haryuni, Widodo, E., \& Sudjarwo, E., (2017). Efek penambahan jus \& daun sirih (Piper bettle linn) sebagai aditifpakan terhadap peforma ayam petelur. Jurnal Riset \& Konseptual, 2(4), 429-433.

Horhoruw, W. M., Wihandoyo \& Yuwanto, T., (2009). Pengaruh pemanfaatan rumput laut grcilaria edulis dalam pakan terhadap kinerja ayam fase pullet. Buletin Peternakan,33(1), 816.

Iskender, H., Yenice, G., Dokumacioglu, E., Kaynar, O., Hayirli, A., \& Kaya, A. (2017). Comparison of the effects of dietary supplementation of flavonoids on laying hen performance, egg quality \& egg nutrient profile. British Poultry Science, 58(5), 550-556. https://doi.org/10.1080/00071668.201 7.1349297.

Iwantoro, S. (2018). Study of antibiotics residue on poultry produscts in Indonesia. Jurnal Ilmu Produksi \& Teknologi Hasil Peternakan, 5(1), 29-33.

Khera, N., \& Bhargava, S. (2013). Phytochemical \& pharmacological evaluation of Tectona grandis Linn. Int J Pharm Pharm Sci, 5(3), 923927.

Kushwah, A. S. (2013). In-Vitro antioxidant potential \& phytochemical screening of Tectona grandis Linn. leaves. In Vitro, 10(11), 12.

Magdalena, S., Natadiputri, G. H., Nailufar, F., \& Purwadaria, T. (2014). Utilization of natural products as functional feed. Wartazoa. Indonesian Bulletin of Animal \& Veterinary Sciences, 23(1), 31-40.
Prabakar, G., Gopi, M., Karthik, K., Shanmugana, S., Kirubakara, A., \& Pavulraj, S. (2016). Phytobiotics: could the greens inflate the poultry production. Asian Journal of Animal \& Veterinary Advances, 11(7), 383392.

https://doi.org/10.3923/ajava.2016.38 3.392.

Prahadi, J. A., Widodo, E., \& Djunaidi, I. H. (2015). Pengaruh penambahan sari belimbing wuluh (Averrhoa bilimbi L.) sebagai acidifier dalam pakan terhadap penampilan produksi ayam petelur. Jurnal Nutrisi \& Makanan Ternak, 1(1), 10-18.

Rahardhinata, F., \& Sani, E. Y., (2012). Ekstraksi antosianin daun jati menggunakan komponen pelarut etanol, asam asetat \& air terhadap rendemen, fenol, flavonoid \& aktivitas antioksidan. Jurnal Teknologi Pangan \& Hasil Pertanian, 10(1), 34-43.

Ramiah, S. K., Zulkifli, I., Rahim, N. A. A., Ebrahimi, M., \& Meng, G. Y. (2014). Effects of two herbal extracts \& virginiamycin supplementation on growth performance, intestinal microflora population \& fatty acid composition in broiler chickens. Asian-Australasian Journal of Animal Sciences, 27(3), 375-382. https://doi.org/10.5713/ajas.2013.130 30.

Sahay, M., \& Sharma, R.,(2015). Antioxidant activity of tectona grandis linn stem bark extract. International Journal of Innovative Science, Engineering \& Technology, 2(11), 906-908 
Satria, E. W., Sjofjan, O., \& Djunaidi, I. H. (2016). Respon pemberian tepung daun kelor (Moringa oleifera) pada pakan ayam petelur terhadap penampilan produksi \& kualitas telur. Buletin Peternakan, 40(3), 197.

Siloto, E. V., Sartori, D. R. S., Oliveira, E. F. A., Sartori, J. R., Fascina, V. B., \& Berto, D. A. (2011). Performance \& egg quality of laying hens fed diets containing aflatoxin, fumonisin \& adsorbent. Revista Brasileira de Ciência Avícola, 13(1), 21-28.
Sinurat, A. P., Purwadaria, T., Togatorop, M. H., \& Pasaribu, T. (2003). Pemanfaatan bioaktif tanaman sebagai "feed additive" pada ternak unggas: Pengaruh pemberian gel lidah buaya atau ekstraknya dalam ransum terhadap penampilan ayam pedaging. JITV, 8(3), 139-145.

Świątkiewicz, S., Wlosek, A. A., Krawczyk, J., Szczurek, W., Puchała, M., \& Józefak, D.(2018). Effect of selected feed additives on egg performance and eggshell quality in laying hens fed a diet with standard or decreased calcium content. Animal Science, 18(1).167-182. 